ABSORTIVE CAPACITY DIMENSIONS ANALYSIS IN TECHNOLOGY PARKS

DOI: $10.19177 /$ reen.v14e22021246-276

\title{
ANÁLISE DE DIMENSÕES DE CAPACIDADE ABSORTIVAS EM PARQUES TECNOLÓGICOS
}

\section{ANÁLISIS DE DIMNENSIONES DE CAPACIDAD ABSORTIVAS EM PARQUES TECNOLÓGICOS}

\section{Daniela Carolina Eckert}

Mestra em Gestão e Negócios pela Universidade do Vale do Rio do Sinos (UNISINOS) e Master Business Administration pela Universidade Poitiers - França

Coordenadora na área de Internacionalização no Tecnopuc- Parque Tecnológico da Pontifícia Universidade Católica do Rio Grande do Sul (PUC-RS)

\section{Luís Felipe Maldaner}

Ph. D. em Estudos Latino Americanos pela Hankuk University of Foreign Studies - Seul, Coreia do Sul Professor na Universidade do Vale do Rio do Sinos (UNISINOS)

\section{Flávia Siqueira Fiorin}

Mestra em Gestão e Negócios pela Unisinos e Master Business Administration pela Universidade Poitiers da França

Gestora de Equipe no Tecnopuc - Parque Tecnológico da Pontifícia Universidade Católica do Rio Grande do Sul (PUC-RS)

Artigo recebido em 02/06/2020. Revisado por pares em 13/09/2020. Reformulado em 15/09/2020. Recomendado para publicação em 17/08/2021, por Ademar Dutra (Editor Científico). Publicado em 31/08/2021. Avaliado pelo Sistema double blind review.

CCopyright 2021 UNISUL-PPGA/Revista Eletrônica de Estratégia \& Negócios. Todos os direitos reservados. Permitida citação parcial, desde que identificada a fonte. Proibida a reprodução total.

Revisão gramatical, ortográfica e ABNT de responsabilidade dos autores. 


\section{ABSTRACT}

The objective of this research is to analyze how the dimensions of the absorptive capacity are evidenced, from the processes of environmental scanning, as it is important to understand the mechanisms that are determinant for these evolutions. In order to validate the interview script, a pilot test was provided with the manager of Barcelona's La Salle Technova. After that, interviews with managers of five Tech Parks in Brazil, one in Spain, and one in South Africa were carried out. The results show a positive influence of the surveyed dimensions on the absorptive capacity of the technology parks.

Keywords: Technology Parks; Environmental scanning; Absorptive capacity.

\section{RESUMO}

O objetivo desta pesquisa é analisar como são evidenciadas as dimensões da capacidade de absorção, a partir dos processos de varredura ambiental, pois é importante compreender os mecanismos determinantes para essas evoluções. Para validar o roteiro da entrevista, foi realizado um teste piloto com o gerente da La Salle Technova de Barcelona. Em seguida, foram realizadas entrevistas com gerentes de cinco Parques Tecnológicos no Brasil, um na Espanha e outro na África do Sul. Os resultados mostram uma influência positiva das dimensões pesquisadas na capacidade de absorção dos parques tecnológicos.

Palavras-chave: Parques Tecnológicos; Digitalização ambiental; Capacidade de absorção.

\section{RESUMEN}

El objetivo de esta investigación es analizar cómo se evidencian las dimensiones de la capacidad de absorción, a partir de los procesos de escaneo ambiental, porque es importante comprender los mecanismos que son determinantes para estas evoluciones. Para validar el guión de la entrevista, se proporcionó una prueba piloto con un gerente de La Salle Technova de Barcelona. Posteriormente se realizaron entrevistas con gerentes de cinco parques tecnológicos en Brasil, uno en España y uno en Sudáfrica. Los resultados muestran una influencia positiva de las dimensiones encuestadas en la capacidad de absorción de los parques tecnológicos.

Palavras-clave: Parques tecnológicos; Escaneo del ambiente; Capacidad de absorción. 


\section{INTRODUCTION}

The technology parks history began in the late 1950s in the United States from initiatives such as Standford Industrial Park, Triangle Research Park, and Route 128. These clusters of technology-based companies emerged as a result of a series of orchestrated actions by the American government, academia and local industry (LUNARDI, 1997). Innovative products developed in companies located in these environments have spread their businesses globally and contributed to the development of one of the world's largest and most pulsating technology hubs.

Since then, successful models such as Silicon Valley have influenced cities, states, and countries and have impacted the development projects of their respective governments (CASTELLS; HALL, 1994). From the point of view of public policies, technological parks are naturally considered as instruments of local competitive advantage (ANNERSTEDT, 2006). And that is why it can be observed an increase in the number of these environments around the world in the last decades, turning into an international phenomenon (PHAN; SIEGEL; WRIGHT, 2005; ANNERSTEDT, 2006).

At the forefront of these changes are the technology-based companies, and the entire ecosystem in which they are embedded. In this way, it is only natural that technological parks have evolved in their models to meet the market demands; from physical spaces for the installation of spin-offs originated in universities, to interactive ones that offer diversified services, where the focus is on the innovation activities based on two-way knowledge, and information flow among ecosystem participants (GYURKOVICS; LUKOVICS, 2014). This creation of synergy and networking between companies and between companies and research institutions is one of the main objectives of technology parks (HASSINK; HU, 2012).

Recently, new organized environments called Innovation Areas have gained prominence and relevance in the innovation ecosystem and have led the International Association of Technology Parks and Areas of Innovation (IASP) to include these new organizations among its members. Discussions on this new concept are based on the "Learning Villages" theory (SANZ, 2001) that combines business spaces with educational centers and 
residential areas, places where it is possible to work and live in a society based on knowledge economy (NIKINA; PIQUE, 2016).

In October 2017, the International Association of Science Parks and Areas of Innovation (IASP) asked their associates, through an online survey. Most of the respondents (70\%) identified the hybrid spaces designated as innovation areas and central areas of the city as the main competitors of the parks. Coworking spaces also pose a threat to $23 \%$ of respondents. Only $13 \%$ of respondents identified other technology parks as competitors (IASP, 2017).

Thus, scanning the environment becomes a critical activity in the management of technological parks, to guarantee the survival and performance of these environments. Environmental scanning is defined as the acquisition and use of information about events and trends in the external environment of an organization, whose knowledge assists management in planning the organization's future courses of action (CHOO; AUSTER, 1993).

Therefore, starting from the understanding that technological parks are environments capable of absorbing new information, processing it, and evolving over time, it is important to understand the mechanisms that are determinant for these evolutions. An interesting way forward in this line is to understand the capacity of technology parks to absorb external knowledge and transform it into value for its stakeholders.

The absorptive capacity was presented by Cohen and Levinthal (1990) as the firm's ability, based on prior knowledge, to recognize the value of new information, assimilate it and apply it for commercial purposes. Since then, researchers have pointed out that the absorptive capacity is an important factor in the innovation process and the creation and maintenance of competitive advantage. Zahra and George (2002) contributed to the academic literature of the absorptive capacity, bringing a more processual perspective of the construct. The authors divide the absorptive capacity into potential and realized, defining the dimensions of acquisition, assimilation, transformation, and exploitation of knowledge, as the main capacities that influence the results of organizations.

In this context, this research aims to verify how the dimensions of the absorptive capacity are evidenced in the technological parks, from the environmental scanning processes, in order to cover a gap in the literature.

Revista Eletrônica de Estratégia \& Negócios, Florianópolis, v.14, n. 2, mai./ago. 2021. 


\section{THEORETICAL REFERENTIAL.}

\subsection{ENVIRONMENTAL SCANNING}

Environmental scanning is the acquisition and use of information about events, trends, and relationships in the environment outside the organization, and the knowledge in which management relies on planning future actions (CHOO, 2001). Organizations scan the environment to reduce blindness, avoid potential surprises, identify threats and opportunities, gain competitive advantage, and improve long-term and short-term planning (ALBRIGHT, 2004; CHOO, 2001).

Scanning and analyzing the environment helps the company to find technological and market opportunities and trends increasing the ability of companies to enter new domains (DAFT; SORMUNEN; PARKS, 1988). According to Choo (2001), scanning not only improves organizational performance but also increases the level of communication between employees and impacts several areas of the organization, from the strategic point of view to management and shared vision communication.

There are several ways of scanning the environment. The use of a specific source of information by managers is often related to their accessibility to this information, and that is why external networks and personal contacts are the primary sources of information (CHOO; AUSTER, 1993). The process of collecting and analyzing information from a company's external environment includes social, regulatory, technological, political, economic, and industrial areas, and is mostly performed through face-to-face interaction (DAFT; SORMUNEN; PARKS, 1988).

\subsection{ABSORPTIVE CAPACITY}

Cohen and Levinthal (1989) originally introduced the term absorptive capacity in their seminal paper as the company's ability to identify, assimilate, and exploit environmental knowledge. A year later, Cohen and Levinthal (1990) redefined the construct as a company's ability to recognize the value of new external information, assimilate it, and apply it for business purposes. According to the authors, the purpose of the absorptive capacity is to 
increase the innovative performance of a company in an uncertain environment through the process of recognition, assimilation, and application of knowledge.

Cohen and Levinthal (1990) argue that the ability to assess and use external knowledge depends on prior knowledge, and that, combined with existing learning experiences, increases the ability to acquire new knowledge while increasing the ability to apply them. Therefore, due to the absorption capacity existing in a specific domain, the identification and assimilation of future knowledge will be more efficient.

According to Cohen and Levinthal (1990), the absorptive capacity of a firm depends on the absorptive capacities of its members, and therefore, an organizational absorptive capacity will develop with the investment in the absorptive capacities of the employees. However, the absorption capacity of a company cannot be seen only as of the sum of the absorption capacities of its employees, as it is necessary to consider how knowledge is shared and exploited throughout the organization. Therefore, the absorptive capacity does not only refer to the acquisition and assimilation of knowledge, but also to the organization's capacity to exploit it.

Cohen and Levinthal (1990) also highlight the importance of organizational communication. The interactions between individuals with diverse knowledge increase the organization's ability to make new connections and associations, stimulating the generation of new ideas and promoting innovation (COHEN; LEVINTHAL, 1990).

Zahra and George (2002) present the absorptive capacity as a dynamic capacity, through which the organization adapts to the external environment. The authors consider the absorptive capacity as a set of routines and organizational processes through which companies acquire, assimilate, transform and exploit knowledge for the purpose of developing new organizational capacities, creating value, and achieving competitive advantage.

In a reconceptualization of the concept, Zahra and George (2002) proposed a distinction between the potential absorptive capacity and realized absorptive capacity, suggesting that the absorptive capacity of the firm be analyzed in these two separate dimensions. The potential absorptive capacity consists in the acquisition and assimilation of Revista Eletrônica de Estratégia \& Negócios, Florianópolis, v.14, n. 2, mai./ago. 2021. 
knowledge and the absorptive capacity realized consists in the transformation and exploitation of knowledge.

"The importance of informal relationships with service providers to strengthen the absorptive capacity of IT areas, which are typically strapped by small budgets and tight time frames, as was the case of the companies investigated." (MORENO; COELHO; PITASSI, 2020, p. 109). At the same time, those authors found that there is a relative degree of translation of this into an effective innovation, depending on the alignment between the absorptive capacity and the business internal area.

In their research, Ferreira and Ferreira (2017) collected data from companies regarding the period between October 2015 and January 2016. It was obtained the return of 273 companies, of which 241 were considered family firms. The relationships developed and supported by the empirical part support the results of Zahra and George (2002) which is that the absorptive capacity helps the extent of innovation.

\subsubsection{Antecedents of Absorptive Capacity}

Based on this reconceptualization of the concept, many researchers have devoted their studies to the validation of the construct of the absorptive capacity and its dimensions, developing hypotheses, variables and validating antecedents through the models in their own studies. In this section, the main antecedents that were validated by the researchers, and that are adherent to the environment of technology parks are presented, following the dimensions proposed by Zahra and George (2012).

Acquisition: According to Flatten et al. (2011), the acquisition dimension of the absorptive capacity is related to the acquisition of external information through various sources, mainly market-related information, through environmental scanning.

For Daghfous (2004), external knowledge is crucial for the development of the absorptive capacity and the interaction with the external environment improves the development of new capacities. Companies that establish partnerships with other companies and knowledge networks (research institutions and universities) are more likely to absorb 
innovative practices due to the abundance of knowledge (DAGHFOUS, 2004; ZAHRA; GEORGE, 2002).

Tu et al. (2006) state that the search for new knowledge is the company's ability to scan the internal and external environment. This scanning is important for the absorptive capacity because it identifies new knowledge that can impact the company. These activities may include monitoring patents, published articles, conferences, the internet, and other businesses that may be sources of innovation (TU et al., 2006).

Camisón and Forés (2010) analyzed the potential absorptive capacity of acquisition from the knowledge of competitors, openness with the environment (trends and opportunities), and cooperation with institutions, universities, and companies.

Moreover, the participation of employees in the company's decision-making is considered by some researchers as an influencing factor in the acquisition of new knowledge (COHEN; LEVINTHAL, 1990; JANSEN; VAN DEN BOSCH; VOLBERDA, 2005). Participation in decision-making allows the employee's contact with a variety of new perspectives, transforming them into new receivers and facilitators of the acquisition of new knowledge (COHEN; LEVINTHAL, 1990; JANSEN; VAN DEN BOSCH; VOLBERDA, 2005).

Assimilation: According to Cohen and Levinthal (1990), the intensity of individual exposure of a company member to prior knowledge is critical in the development of absorptive capacity, and companies with a diversified history of knowledge more readily relate prior knowledge with new knowledge. Without prior knowledge, organizations are not able to assimilate the new information and, thus, will have more difficulty absorbing it. (COHEN; LEVINTHAL, 1990; TODOROVA; DURISIN, 2007; ZAHRA; GEORGE, 2002).

The level of education of the workforce was one of the indicators used by Vega-Jurado, Gutiérrez-Gracia and Fernández-De-Lucio et al. (2008). The authors state that companies with teams with a high level of education and qualification will have better performance while assimilating and transforming external knowledge, and therefore, higher levels of absorptive capacity. The educational history of the employees is a key aspect of the absorptive capacity of the companies (MINBAEVA et al., 2003; VEGA-JURADO; GUTIÉRREZ-GRACIA; FERNÁNDEZDE-LUCIO, 2008).

Revista Eletrônica de Estratégia \& Negócios, Florianópolis, v.14, n. 2, mai./ago. 2021. 
Van den Bosch, Van Wijk and Volberda (2003) emphasize the importance of shared language and suggest that prior knowledge and internal organizational mechanisms should be considered as key factors influencing absorptive capacity. Prior knowledge includes basic skills and learning experience, and organizational mechanisms refer to internal factors, such as the structure of communication and distribution of knowledge.

The absorptive capacity can be developed as a by-product of the routine activities of a company that wishes to exploit knowledge related to the current expertise. However, when the desired knowledge is not related to the company's ongoing activities, investment in training is necessary for the development of the absorptive capacity (COHEN; LEVINTHAL, 1990). Daghfous (2004) also emphasizes the importance of organizational learning and investing in activities such as employee training.

Companies should invest in resources to capacitate and training programs, even if the results of such investment are not immediate (COHEN; LEVINTHAL, 1990; DAGHFOUS, 2004). Murovec and Prodan (2009) have shown that internal R \& D, staff training, cooperation in innovation, and a positive attitude towards change are the most important antecedents of organizational absorptive capacity. The ability of employees to assimilate new knowledge, involvement in research, and participation in professional events and training were also factors analyzed by Camisón and Forés (2009).

Communication between the organization and the external environment is important, as well as between units and members within the organization. A dense network of communication between the organization's areas motivates employees to help each other and allows an interaction that helps in the interpretation of new external knowledge (JANSEN; VAN DEN BOSCH; VOLBERDA, 2005). Communication and knowledge sharing can be transmitted in various ways within an organization. Workshops, seminars, formal and informal sharing structures among groups, departments, and business units, and face-to-face interactions are examples of effective tools for building and maintaining innovation networks (LEWIN; MASSINI; PEETERS, 2011).

Transformation: According to Zahra and George (2002), the gap between potential and realized absorptive capacity is reduced using social integration mechanisms. These 
mechanisms contribute to the assimilation of knowledge and might be informal, such as social or formal networks. Informal mechanisms work while exchanging ideas, while formal mechanisms allow a more systematic integration of knowledge. With formal mechanisms of social integration, information can be effectively distributed within the company, interpretations can be collected, and trends can be identified (ZAHRA; GEORGE, 2002).

According to Daghfous (2004), the organizational structure also influences how well the knowledge acquired can be transferred within the organization to those involved. The organization must be flat, dynamic, adaptable, flexible, participatory, and have a minimum of bureaucracy. Organizational culture should be open to change, and employees should feel free to suggest improvements in processes and try out new ideas (DAGHFOUS, 2004). The generation of ideas is also pointed out by Flatten et al. (2011) as a factor related to the transformation of knowledge within organizations since the creation of something new is a combination of existing knowledge with the newly acquired.

Multidisciplinary workgroups, the delegation of responsibilities, and a system for collecting employee proposals are some of the practices that influence the transformation in the absorptive capacity of firms (COHEN; LEVINTHAL, 1990; DAGHFOUS, 2004; JANSEN; VAN DEN BOSCH; VOLBERDA, 2005; VEGA-JURADO; GUTIÉRREZ-GRACIA; FERNÁNDEZ-DE-LUCIO, 2008).

The study of Jansen, Van Den Bosch and Volberda (2005) revealed the importance of organizational mechanisms related to socialization capacities that strengthen the organizations' absorptive capacity. Socialization mechanisms build the necessary connection between people in an organization to develop joint knowledge or share and integrate knowledge from different parts of the organization or the external environment (JANSEN; VAN DEN BOSCH; VOLBERDA, 2005; LEWIN; MASSINI; PEETERS, 2011).

According to Daghfous (2004), organizations should have physical and digital spaces where employees can communicate and get together with each other. Knowledge transfer within the company should be facilitated by the informal sharing of organizational knowledge, through seminars and workshops, and by the promotion of open communication (DAGHFOUS, 2004). 
Exploitation: The exploration dimension denotes an organization's ability to improve, expand and use its existing routines, skills, and technologies to create something new based on transformed knowledge, converting knowledge into new products to improve performance and competitive advantage (FLATTEN et al., 2001). The ability of organizations to respond to market demands through new products was also validated by Camisón and Forés (2009) for the exploration dimension in their measurement instrument.

For Camisón and Forés (2009), the realized absorptive capacity represents the company's ability to integrate and reconfigure existing internal knowledge and newly assimilated knowledge and incorporate this knowledge transformed into the routines and operations of the organization, not only to refine the knowledge and skills but also to create new operations and skills.

Cohen and Levinthal (1990) argue that the absorptive capacity is also related to the way an organization develops routines and processes to internalize and apply external knowledge. Formalization supports the access to the knowledge that has already been internalized, increasing the likelihood that organization members will identify opportunities for the transformation of new knowledge (JANSEN; VAN DEN BOSCH; VOLBERDA, 2005). According to the authors, through formalization, organizations encode best practices, making knowledge more efficient to exploit, easier and faster to implement.

The registration of information, the documentation of information made available periodically, the easy access to this information, as well as the responsibility for its use, are part of the exploitation of knowledge (JIMÉNEZ-BARRIONUEVO; GARCÍA-MORALES; MOLINA, 2011; TU et al., 2006).

Schweisfurth and Raasch (2018, p. 695) found in their study the importance of absorptive capacity "as a mechanism to explain how external need knowledge is identified, assimilated, and applied for product innovation in firms". Need knowledge and solution knowledge are known to be two necessary prerequisites for innovation as is shown in figure 1. 
Figure 1 - Knowledge and Absorptive capacity relations

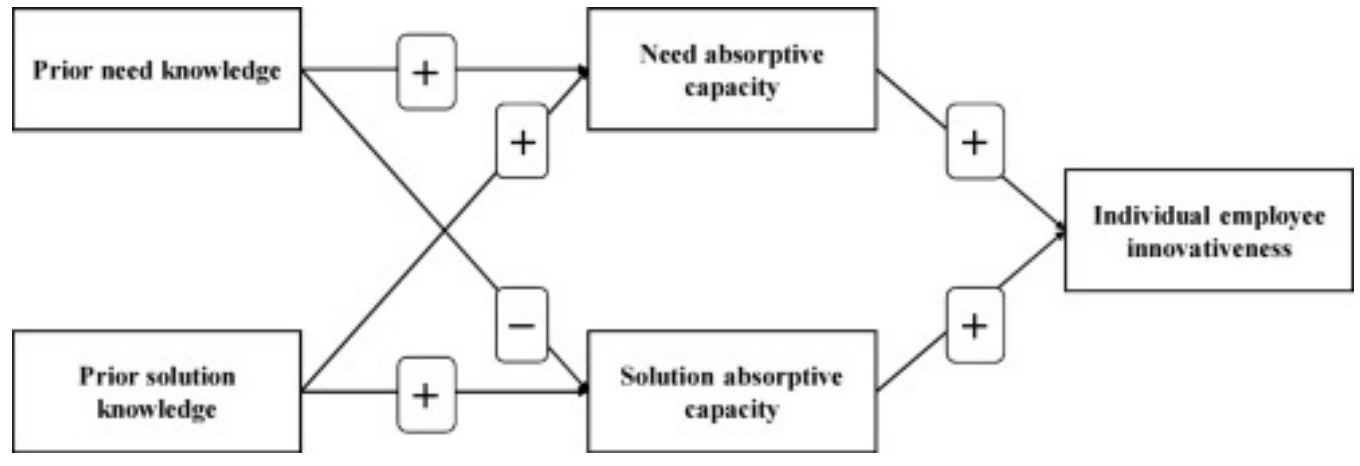

Source: Schweisfurth and Raasch (2018).

The main antecedents identified in the literature are summarized in table 01:

Table 01 - Summary - Evidence of Absorptive Capacity Antecedents in Technology Parks

\begin{tabular}{|c|c|c|c|}
\hline $\begin{array}{c}\text { Absorptive Capacity } \\
\text { Dimensions }\end{array}$ & $\begin{array}{c}\text { Antecedents of } \\
\text { Absorptive Capacity }\end{array}$ & Theoretical Basis & $\begin{array}{c}\text { Absorptive Capacity } \\
\text { Dimensions }\end{array}$ \\
\hline \multirow{3}{*}{$\begin{array}{l}\text { Potential Absorptive } \\
\text { Capacity (Acquisition) }\end{array}$} & Environmental Scanning & $\begin{array}{l}\text { Cohen e Levinthal } \\
\text { (1990); Daugfous (2004); } \\
\text { Tu et. Al. (2006); } \\
\text { Camisón and Forés } \\
\text { (2009); Flatten et. al. } \\
\text { (2011); Lewin, Massini } \\
\text { and Peeters (2011) }\end{array}$ & $\begin{array}{l}\text { Potential Absorptive } \\
\text { Capacity (Acquisition) }\end{array}$ \\
\hline & $\begin{array}{l}\text { Cooperation with other } \\
\text { organizations }\end{array}$ & $\begin{array}{l}\text { Cohen e Levinthal } \\
\text { (1990); Tu et. Al. (2006); } \\
\text { Camisón and Forés } \\
\text { (2009); Flatten et. al. } \\
\text { (2011) }\end{array}$ & \\
\hline & $\begin{array}{l}\text { Participation in Decision } \\
\text { Making }\end{array}$ & $\begin{array}{l}\text { Cohen e Levinthal } \\
\text { (1990); Daugfous, 2004; } \\
\text { Jansen, Van den Bosch e } \\
\text { Volberda (2005) }\end{array}$ & \\
\hline \multirow{3}{*}{$\begin{array}{l}\text { Potential Absorptive } \\
\text { Capacity (Assimilation) }\end{array}$} & $\begin{array}{l}\text { Employee Education } \\
\text { Level }\end{array}$ & $\begin{array}{l}\text { Cohen and Levinthal } \\
\text { (1990); Tu et. Al. (2006); } \\
\text { Vega-Jurado et. al. } \\
\text { (2008) }\end{array}$ & $\begin{array}{l}\text { Potential Absorptive } \\
\text { Capacity (Assimilation) }\end{array}$ \\
\hline & $\begin{array}{l}\text { Training and } \\
\text { Development Programs }\end{array}$ & $\begin{array}{l}\text { Daugfous (2004); Jansen } \\
\text { et. al. (2005); Tu et. Al. } \\
\text { (2006); Camisón and } \\
\text { Forés (2009) Murovec } \\
\text { and Prodan (2009); }\end{array}$ & \\
\hline & Communication & $\begin{array}{l}\text { Cohen and Levinthal } \\
\text { (1990); Daugfous (2004); } \\
\text { Jansen et. al. (2005); } \\
\text { Flatten et. al. (2011); } \\
\text { Lewin et. al., (2011) }\end{array}$ & \\
\hline $\begin{array}{l}\text { Realized Absorptive } \\
\text { Capacity (Exploitation) }\end{array}$ & Job Rotation & $\begin{array}{l}\text { Cohen and Levinthal } \\
\text { (1990); Daugfous (2004); } \\
\text { Jansen et. al. (2005) }\end{array}$ & Job Rotation \\
\hline
\end{tabular}

Revista Eletrônica de Estratégia \& Negócios, Florianópolis, v.14, n. 2, mai./ago. 2021. 


\begin{tabular}{|c|c|c|c|}
\hline $\begin{array}{c}\text { Absorptive Capacity } \\
\text { Dimensions }\end{array}$ & $\begin{array}{c}\text { Antecedents of } \\
\text { Absorptive Capacity }\end{array}$ & Theoretical Basis & $\begin{array}{l}\text { Absorptive Capacity } \\
\text { Dimensions }\end{array}$ \\
\hline & Socialization & $\begin{array}{l}\text { Daugfous (2004); Jansen } \\
\text { et. al. (2005); Flatten et. } \\
\text { al. (2011) }\end{array}$ & Socialization \\
\hline & $\begin{array}{l}\text { New knowledge } \\
\text { application, idea } \\
\text { generation }\end{array}$ & $\begin{array}{l}\text { Daugfous (2004); Jansen } \\
\text { et. al. (2005); Flatten et. } \\
\text { al. (2011). }\end{array}$ & $\begin{array}{l}\text { New knowledge } \\
\text { application, idea } \\
\text { generation }\end{array}$ \\
\hline \multirow{2}{*}{$\begin{array}{l}\text { Realized Absorptive } \\
\text { Capacity (Exploitation) }\end{array}$} & Formalization Tools & $\begin{array}{l}\text { Tu et. Al. (2006); Jansen } \\
\text { et. al. (2005); Jiménez- } \\
\text { Barrionuevo et. al. } \\
\text { (2011). }\end{array}$ & $\begin{array}{l}\text { Realized Absorptive } \\
\text { Capacity (Exploitation) }\end{array}$ \\
\hline & $\begin{array}{l}\text { Generation of new } \\
\text { products and services }\end{array}$ & $\begin{array}{l}\text { Camisón and Forés } \\
\text { (2009); Flatten et. al. } \\
\text { (2011) }\end{array}$ & $\begin{array}{l}\text { Generation of new } \\
\text { products and services }\end{array}$ \\
\hline
\end{tabular}

Source: Elaborated by the authors, 2021.

\section{METHODOLOGY}

The multiple case study method was chosen as a research methodology for the present study, which sought to find evidence of the dimensions of the absorptive capacity in technological parks from environmental scanning processes.

According to Yin (2009), a case study investigates a contemporary phenomenon within its real-life context, especially when the boundaries between phenomenon and context are not clearly defined. The method chosen is appropriate since it is difficult to separate the context from the absorptive capacity on technology parks related to the environmental scanning processes from the wider context in which these capabilities are developed.

The choice of multiple cases was since it shows similarities and differences between the cases studied and allows identifying the complementarities between one case and another, to enrich the analyzes so that other parks can improve their perspectives on the development of the absorptive capacity.

The cases selected for the study were TECNOPUC, Tecnovates, São José dos Campos Technological Park (PqTec), Porto Digital, Cartuja Science and Technology Park (PCT Cartuja), and Johanneberg Science Park (JSP). The selected cases met the following criteria: 1) consolidated parks in the phase of operation; 2) parks affiliated to the IASP; 3 ) availability of management for participation in research. 
The primary data were collected through in-depth interviews with the technology park managers, supported by a semi-structured script, conducted personally by the researcher, and complemented by direct participant observation. In order to conduct the interviews for the study, a script of questions was elaborated by the researcher, based on the theoretical conceptual base.

The interview script was based on the main studies on the absorptive capacity, selecting elements with a positive influence on the absorptive capacity of the organizations, as evidenced by statistical studies. The researcher identified important elements for the development of the absorptive capacity to compose the categories that guided the elaborated questions.

In order to validate the interview script, a pilot test was carried out with a manager of a technology park that met the criteria established in the research. The selected park was Barcelona's La Salle Technova, whose manager is also the president of IASP.

The methodology used to describe and interpret the content of the interviews was the content analysis, which allows a reinterpretation of the messages to reach a deeper understanding, besides a simple reading (MORAES, 1999). According to Bardin (1995), the content analysis still enriches the exploratory attempt, increasing the propensity to discovery.

After conducting the interviews with the managers of the selected parks, a literal transcription of the interviews was carried out generating a volume of 65 pages. The next step was a careful reading of all the transcribed material. The categories were defined based on the theoretical basis and the results were described and interpreted according to the theory.

\section{RESULTS}

This study does not intend to compare the results of the technology parks, but to discuss the pieces of evidence found in the organizational dynamics of each park and that refers to the development of the absorptive capacity during the process of environmental scanning. 


\subsection{POTENTIAL ABSORPTIVE CAPACITY - ACQUISITION}

Environmental Scanning: From the interviewees' report, it is noticed that the environmental monitoring is carried out by the analyzed parks, from different activities. National and international forums were pointed out by the managers of Tecnovates, TECNOPUC, PqTec, and JSP as sources of information, mainly for benchmarking the best practices related to the environment of technology parks and incubators.

Porto Digital has a more consolidated process of environmental monitoring, starting with extensive biennial market research, in which economic data are collected from companies such as sales and market performance, and issues related to the human capital profile, such as sex, age, habits, qualification demands. The result of the research is mainly used by the management as a source of knowledge and information that will be worked on at the strategic level.

This information should be commented on daily by the park team, with the intention of provoking interactions with the entrepreneurs who have access to the platform. Other actions related to the project are monthly seminars addressing the most discussed topics on the platform, and larger events with large companies every three months (CAMISÓN; FORÉS, 2009; LEWIN; MASSINI; PEETERS, 2011; TU et al., 2006; ZAHRA; GEORGE, 2002). Although it addresses large types of information, acquisition as a dimension of the absorptive capacity is also related to the generation of knowledge and market-oriented intelligence, through investments in the search for new and relevant information outside the organization (FLATTEN et al., 2011). Although well-structured, the park manager notes that, due to a lack of staff especially dedicated to the operation of the program, "Mind the Future" has not been updated with the proposed frequency.

Cooperation with other organizations: Cooperation with other institutions and companies was mentioned by all the interviewees as a source of acquisition of new knowledge and exchange of information, both in national and international networks. At Tecnovates, despite the current international agreements focused mainly on the exchange of information at the management level, the park is working to intensify the exchange of people, promoting a more enriching exchange of experiences and knowledge.

Revista Eletrônica de Estratégia \& Negócios, Florianópolis, v.14, n. 2, mai./ago. 2021. 
At PCT Cartuja, one of the cooperation agreements mentioned was with the research institute of the European Commission. At TECNOPUC and JSP, the managers interviewed indicated the importance of cooperation agreements with other institutions being based on concrete actions so that information exchange will be efficient. According to the manager of TECNOPUC, unless there is a specific event or program, there will be no connection and participation of people, therefore, the agreement ends up becoming merely institutional. In the JSP, the director also highlights the cooperation with international partners through interconnected projects, such as partners linked to the Horizon 2020 Project, one of the largest projects to encourage and fund innovative projects in the European Union.

In addition to the cooperation and agreement with other parks and sectoral clusters, with which there is a constant exchange of information, the PqTec interviewee also mentions the importance of the relationship with the Brazilian Industrial Development Agency (ABDI) and the Brazilian Agency for the Promotion of Exports and Investments (APEX).

In general, the interviewees' discourse shows great importance to the openness of the environment referenced by Camisón and Forés (2009), and to the relationship and cooperation with other institutions in the search for information, new knowledge, and tendencies (DAGHFOUS, 2004; ZAHRA; GEORGE, 2002;).

Participation in decision making: The shared decisions were mentioned mainly by two parks, TECNOPUC and Porto Digital. For the TECNOPUC interviewee, the shared decision with the team members is a way to promote engagement and the feeling of belonging.

In Porto Digital, Tuesday's formal meetings are the main moment of sharing between the team, and where everyone can contribute with suggestions regarding, mainly, internal processes. With respect to the issues that involve the biggest deliverables of the Digital Port for the ecosystem, decisions are made at the management level, but with the contribution of the respective teams.

The PCT Cartuja is undergoing a reformulation of the strategic plan now. The park is completing 25 years, and planning has been done to define the next 25 years of the park. The participation of employees in future strategic decisions was highlighted by the interviewee as essential. There is an open document on a cloud platform that can be accessed by all Revista Eletrônica de Estratégia \& Negócios, Florianópolis, v.14, n. 2, mai./ago. 2021. 
employees. All are authorized, and encouraged, to insert contributions, and the digital record of who contributed. Although the final decision is under the responsibility of the board, all employees are informed about the content of the document and can actively participate in the decisions with their contributions.

The interviewee of Tecnovates reports that when issues that require decision-making arise, they are already accompanied by a proposal from the stakeholders. In this way, as far as possible, the decision is made according to the suggestions brought by the team.

TECNOPUC has recently undergone a reformulation of its management model. For 8 months, data collection and analysis activities were carried out, discussions in large and small groups, aiming to propose the new structure model. One of the results of this process was the finding that the solutions are not centralized in the top management but are constantly cocreated by the teams. The implementation of the management model based on interconnected nodes, in a network format, was accompanied by the creation of a "safety zone" where teams can feel empowered to make decisions. According to the interviewee, besides the increased demand for communication between peers, it can be noticed a greater interaction of the team with the community of TECNOPUC, including companies and researchers of the university. This result shows that the greater participation of the employees in the decision-making process has turned them into prospective "receivers" of new information (COHEN; LEVINTHAL, 1990; JANSEN; VAN DEN BOSCH; VOLBERDA, 2005).

\subsection{POTENTIAL ABSORPTIVE CAPACITY - ASSIMILATION}

Employee Education Level: Although it does not have a team specifically trained to manage innovative environments, Tecnovates works with a highly qualified team of technicians to assist the park's laboratory structures, and especially professionals qualified to meet the communication needs between researchers and companies.

The need for a qualified team is also pointed out by the TECNOPUC interviewee as fundamental to be part of the management and operational team of the park: "I cannot imagine the case of someone who works in an area where she or he does not master, of course the person may not be the greatest expert, but they must have experience in the field, and the necessary qualification." (TECNOPUC)

Revista Eletrônica de Estratégia \& Negócios, Florianópolis, v.14, n. 2, mai./ago. 2021. 
PTC Cartuja and JSP also claim to have a qualified team and point out the diversity of formal education as one of the positive aspects of their team composition. At PqTec, employees are recruited in an organized formal process that bases the hiring at the required technical level according to the demand and profile of each position, from the direction to the trainee, and the formal knowledge is widely valued.

At Porto Digital, the requirement for specialization is considered fundamental for the composition of the team, and half of the employees in the management team have a master's or doctorate degree. According to the interviewee, even the oldest employees sought specialization, especially those who work with project management.

The interviews show that the parks have teams with a diverse knowledge base and that the level of education and technical knowledge of the employees is high and diversified, facilitating the assimilation of external information acquired (COHEN; LEVINTHAL, 1990; ZAHRA; GEORGE, 2002).

Training and Development Programs: Regarding training and development activities, Tecnovates and PCT Cartuja showed the qualification of the team as a consolidated organizational process. At PCT Cartuja, a development plan is constructed for everyone every year, according to their personal needs. At Tecnovates, the development plan is carried out by the people development sector of the University, which has innovation capabilities as a strategic area of development.

At Porto Digital, the training is directly linked to the career plan, and the evolution of the employees will depend on their response to this training: "It's something that works, we have a career model, and the evolution of people is basically conditioned by the response they give within their own qualification." (Porto Digital).

However, some of the interviewees recognize the need for a more structured process, such as the JSP, where capacity building depends on resources available within the projects. At PqTec and TECNOPUC, there is a concern to train employees, but there is no structured program for that, and the training is offered according to demand and opportunity. 
Communication: The results show that the means of communication adopted by most of the researched environments, for the dissemination of the information captured in the external media, is through meetings that happen regularly.

At PqTec, although some meetings are only at the board level, once a week a meeting takes place with all coordinators involving all programs and actions. According to the interviewee: "At these meetings, feedback is also given on all the activities being developed, and participation in forums, events and trips are always reported to everyone who is attending to the meeting."

At PCT Cartuja, meetings to discuss strategic issues are held with the four directors on a fortnightly basis, team meetings are held daily in the early morning. It is during these daily meetings that the information collected in events, trips, and external activities are shared. The daily meetings are done in a very informal format, during a breakfast set.

In Porto Digital, every Tuesday a meeting is held, with all the team, to share on various subjects and to update on projects in progress. According to the interviewee, this is a formal moment, where information about participation in events, travel, and discussions about trends are on the agenda. The interviewee notes that sharing occurs easily as well as informally since the whole team shares the same space.

The Tecnovates interviewee says there are regular meetings, but that the exchange of information from environmental monitoring activities happens more promptly when shared by email and "WhatsApp." These tools are also used to communicate information with the park and incubator entrepreneurs.

At TECNOPUC, the interviewee also mentions the meetings as moments for sharing this information but admits that they could happen more frequently: "every person on the team going to some event has to come back and, at the meeting, share what saw, however, this has not been always followed by the coworkers." (TECNOPUC).

According to Cohen and Levinthal (1990), the absorptive capacity of an organization is not resident in any individual but depends on the link between a mosaic of individual capacities. For the technological parks interviewed, the sharing of information among the 
individuals of the organizations is done mainly through face-to-face meetings. This face-toface interaction generates the trust, respect, and commitment necessary for continuous interaction and knowledge sharing (LEWIN; MASSINI; PEETERS, 2011) and allows an efficient flow of communication between individuals, areas, and departments, a fundamental factor for the assimilation of new information (JANSEN; VAN DEN BOSCH; VOLBERBA, 2005; FLATTEN et al., 2011). 


\subsection{REALIZED ABSORPTIVE CAPACITY - TRANSFORMATION}

Job Rotation: Concerning the rotation of functions, the Digital Port incorporated the activity as a preparation within the career plan. According to the interviewee, the evolution within the organization depends on a more macro view of the business, and the rotation of positions and functions is the most appropriate way for this vision to be developed.

Most of the parks interviewed treat rotation of functions as a more casual and informal activity: "[...] when the areas are close and the activities allow, we do. When there is a restriction by law, especially the labor rules, it is more difficult" (TECNOPUC). "[...] we have that understanding that whoever is there does everything, when it has to be done, so we work like that. [...] So the job rotation happens depending on the demand." (Tecnovates).

Although there is no rotation of functions in the Cartuja PCT, two people are always defined to share responsibility in each project or priority sector. This was the way that there is always an exchange of information between peers, in all projects managed by the technology park. This guideline guarantees that no information will be in the hands and mind of a single employee.

The interviewees' reports show that the rotation of functions is not an established practice in most of the studied parks, happening informally or on-demand. Job rotation at Porto Digital has an impact on professional motivation, collaboration among employees, and contributes to the search for personal and organizational knowledge, increasing the ability to associate new knowledge with existing knowledge.

The interviewees' reports show that the rotation of functions is not an established practice in most of the studied parks, happening informally or on-demand. Rotation of functions in Porto Digital has an impact on professional motivation, collaboration among employees, and contributes to the search for personal and organizational knowledge, increasing the ability to associate new knowledge with existing knowledge (COHEN; LEVINTHAL, 1990; DAGHFOUS, 2004; JANSEN; VAN DEN BOSCH; VOLBERDA, 2005).

Socialization: The JSP team recently moved from office, since the former did not meet the growing needs of the group. At the moment, the team is sharing a large and open space Revista Eletrônica de Estratégia \& Negócios, Florianópolis, v.14, n. 2, mai./ago. 2021. 
with another company, which, according to the interviewee, had positive points in terms of comfort, but had a negative impact on the communication of the team. The highlight was the loss of the small kitchen, the point of socialization of the team, and where communication was more informal. The Cartuja park interviewee also mentioned the space as an informal and relaxed meeting place, where both the park staff and entrepreneurs gather to share information and socialize.

The shared workspaces have also been mentioned by Porto Digital and Tecnovates as the main sites for socialization and sharing: "Most of those who work in the park operations are in the same room, we knocked down the walls that existed, so everyone can connect." (Tecnovates)

TECNOPUC and PqTec highlight the shared areas of common use with companies: "We have basketball and volleyball court, a coworking space, an open coworking cafe, a decompression room that has pool table, ping-pong table, outside areas, stools, plenty of room to socialize, lots of space shared" (TECNOPUC). "[...] in addition to the stimulating environments for networking, such as the cafes, we have spaces for people to sit, and sofas and things scattered throughout the Park so that people can sit and talk" (PqTec).

The interviewees of PqTec and Tecnovates also mentioned the promotion of moments to strengthen the interaction between people: "[...]we promote moments where you combine relaxation and chat, have a "chimarrão", a coffee, or just talk." (Tecnovates). "Sometimes we promote events, like a Pizza event, that participates who feels like and it's an integration event so we have residents, incubated, startups, everyone can participate." (PqTec).

The spaces and activities of connection between the employees promoted by the parks strengthen the social bonds, the degree of trust and integration, and facilitate the exchange of ideas, leading to the adaptation and use of new external knowledge within the organization (DAGHFOUS, 2004; JANSEN; VAN DEN BOSCH; VOLBERDA, 2005; LEWIN; MASSINI; PEETERS, 2011).

New knowledge application and idea generation: At Tecnovates, the generation of new ideas is part of the culture in the institution, which motivates employees to participate with ideas, applying their knowledge. The interviewee mentioned the Inova Univates event, Revista Eletrônica de Estratégia \& Negócios, Florianópolis, v.14, n. 2, mai./ago. 2021. 
which works as a "Startup Weekend" marathon. The event is aimed at employees of the institution and focused on generating ideas for challenges related to it. The winners of the 2017 event were rewarded with a trip and will participate in the ANPROTEC Annual Conference in Rio de Janeiro.

At TECNOPUC, there is also this stimulus in relation to the implementation of new ideas and application of new knowledge: "So we give freedom, we reinforce, we try to create an open environment, so they feel welcome and feel free to do this, but each one responds in his own time." (TECNOPUC).

According to the JSP interviewee, the freedom to propose new ideas occurs mainly when there is a resource available. They also work with an interesting voting system of ideas. The person who has an idea and would like it to be implemented shares with the group through a summary, a "pitch" of a page, and colleagues vote yes or no for the continuity of the project.

In Cartuja, the generation of ideas is also part of the organization's culture. The interviewee mentioned that the two previous administrations were already great promoters of this culture and that the current management also works to foment the generation of new ideas. And this is done almost daily, especially during meetings: "In our company we never punished the error. We may punish the lack of action, but if you make a mistake doing something you believe in, you will never, never be punished." (PCT Cartuja).

At PqTec it was mentioned that hierarchy sometimes gets in the way of implementing new ideas and applying new knowledge. There is a certain level of freedom, but projects that can have a greater impact on park operations are taken to various levels of approval before implementation.

The interviewees' reports refer to what we observe in theory in relation to the factors that positively influence the transformation of knowledge through an open organizational climate to the proposition of new ideas (DAGHFOUS, 2004; JANSEN; VAN DEN BOSCH; VOLBERDA, 2005; FLATTEN et al., 2011) 


\subsection{REALIZED ABSORPTIVE CAPACITY - EXPLOITATION}

Formalization tools: At Tecnovates, the main tool used to keep track of all the information and knowledge gained by park staff is through reports. The interviewee commented that there is a sharing tool, however, the focus of this tool is on the sharing of indicators and goals that are established for the park, so that everyone has access and can feed the information needed.

The JSP is a relatively new park, and the interviewee admits that information management, especially the knowledge acquired by the organization, is still a point that needs improvement.

In Porto Digital and Tecnopuc, the main tool for storing information, resulting from the process of environmental monitoring, is the directory tree management, bringing together diverse contents with a file network. The management is done in a structured way, around a directory tree, in a central server, with accesses allowed by a certain hierarchy.

In São José dos Campos, the interviewee mentioned an incubator monitoring system. The system is an own developed model that ended up being part of the incubation process. This system, which has been in place and running for a few years, has become an important source of information and knowledge storage, especially for the management team.

In the PCT Cartuja, many disconnected tools were used previously, and as it was noticed that a great amount of information was being lost. A new system was implemented recently, and now the information and knowledge acquired can be made available and shared with the entire team, anytime, anywhere, as it works on a cloud system.

Tecnovates and JSP, have more fragile routines for the storage of information and acquired knowledge, which may hinder the recovery of knowledge already internalized for later application for many members of the organization (JANSEN; VAN DEN BOSCH; VOLBERDA, 2005). The other parks studied have more structured information systems, facilitating the access to the information and accumulated knowledge, facilitating the exploration and application of the same for the other members of the team (JANSEN; VAN DEN BOSCH; VOLBERDA, 2005; JIMÉNEZ-BARRIONUEVO; GARCÍA-MORALES; MOLINA, 2011). 
Generation of new products and services: All the parks interviewed mentioned the development of projects, the creation of services and products that could be linked to the activities related to environmental scanning: "[...] everything we do originated in a benchmarking action. If it is not a model itself, it is an inspiration and appropriateness to our possibility." (Tecnovates).

The actions of environmental monitoring and benchmarking were also cited by TECNOPUC, as primordial in creating the products and services that make available to the ecosystem of the park: "[...] everything that we do, what we are, somehow emerged from somewhere. Okay, a lot, maybe because of the university's own conviction, but I would say the great majority is by "benchmarking". [...] I think a lot of what we do today has been shaped by this ability to listen and adapt." (TECNOPUC)

Porto Digital mentioned the importance of being updated with the new technologies and needs of companies and especially of the community. It was from the understanding of these demands that the park idealized the L.O.U. Co, a laboratory designed for the prototyping of products and services that aim to solve the challenges of the cities.

At PCT Cartuja, the crisis of 2008 was an important milestone to seek external knowledge and new models that would allow the maintenance of programs aimed at startups. Before the crisis, there was a lot of public investment for the creation and development of companies through grant resources. With the crisis, the appeal was over, and the park understood that it needed to find other models to finance the companies. After learning about models such as Silicon Valley and innovation environments in England, they decided on a capacity-building model for fundraising "pitch", adapted to the local reality. The pioneering model, now widely adopted by other innovation environments in Spain, has managed to raise the amount of 100 million euros in the six years in which it is running.

In the SJP, the interviewee reports that all the projects the park is working on were idealized by listening to community needs and combined with research in development in academic institutions. The interviewee of PqTec also reinforces that a good part of the services provided by the park is the result of a very close relationship with the companies and the 
understanding of the demands of the region. One of the identified demands was a certification for Embraer's suppliers.

Finally, we can identify in the technological parks surveyed the ability to explore new knowledge, respond to changes in the environment, apply experience to create new products and services, and improve the capacity to meet market demands (CAMISÓN; FORÉS, 2010, FLATTEN et al., 2011).

Table 02 shows the summary of the main results from the interviews with the Techpark managers, organized by the absorptive capacity antecedents identified in each dimension, according to the literature.

Table 2 - Summary - Evidence of Absorptive Capacity Antecedents in Technology Parks

\begin{tabular}{|c|c|c|}
\hline $\begin{array}{l}\text { Absorptive Capacity } \\
\text { Dimensions }\end{array}$ & Antecedents of Absorptive Capacity & Theoretical Basis \\
\hline \multirow{3}{*}{$\begin{array}{l}\text { Potential Absorptive Capacity } \\
\text { (Acquisition) }\end{array}$} & $\begin{array}{l}\text { Environmental Scanning } \\
\text { Participation in forums, innovation } \\
\text { networks, benchmarking activities. } \\
\text { Networking with industry; media } \\
\text { channels; market research. }\end{array}$ & $\begin{array}{l}\text { Cohen e Levinthal (1990); Daugfous, } \\
\text { 2004; Tu et. Al. (2006); Camisón and } \\
\text { Forés (2009); Flatten et. al. (2011); Lewin, } \\
\text { Massini and Peeters (2011) }\end{array}$ \\
\hline & $\begin{array}{l}\text { Cooperation with other organizations } \\
\text { Cooperation with research institutes; } \\
\text { joint projects with other institutions; } \\
\text { relationship with governmental } \\
\text { institutions. }\end{array}$ & $\begin{array}{l}\text { Cohen e Levinthal (1990); Tu et. Al. } \\
\text { (2006); Camisón and Forés (2009); } \\
\text { Flatten et. al. (2011) }\end{array}$ \\
\hline & $\begin{array}{l}\text { Participation in Decision Making } \\
\text { Shared decisions; collective construction; } \\
\text { participation on strategic decision } \\
\text { making. }\end{array}$ & $\begin{array}{l}\text { Cohen e Levinthal (1990); Daugfous, } \\
\text { 2004; Jansen, Van den Bosch e Volberda } \\
\text { (2005) }\end{array}$ \\
\hline \multirow{3}{*}{$\begin{array}{l}\text { Potential Absorptive Capacity } \\
\text { (Assimilation) }\end{array}$} & $\begin{array}{l}\text { Employee Education Level } \\
\text { Formal education is valued; diverse } \\
\text { teams; specialization focused on project } \\
\text { management. }\end{array}$ & $\begin{array}{l}\text { Cohen and Levinthal (1990); Tu et. Al. } \\
\text { (2006); Vega-Jurado et. al. (2008) }\end{array}$ \\
\hline & $\begin{array}{l}\text { Training and Development Programs } \\
\text { Career development programs; training } \\
\text { on demand. }\end{array}$ & $\begin{array}{l}\text { Daugfous, 2004; Jansen et. al., (2005); Tu } \\
\text { et. Al. (2006); Camisón and Forés (2009) } \\
\text { Murovec and Prodan (2009); }\end{array}$ \\
\hline & $\begin{array}{l}\text { Communication } \\
\text { Face to face meetings; e-mails; } \\
\text { WhatsApp; newsletters. }\end{array}$ & $\begin{array}{l}\text { Cohen and Levinthal (1990); Daugfous, } \\
\text { 2004; Jansen et. al., (2005); Flatten et. al. } \\
\text { (2011); Lewin et. al., (2011) }\end{array}$ \\
\hline $\begin{array}{l}\text { Realized Absorptive Capacity } \\
\text { (Transformation) }\end{array}$ & $\begin{array}{l}\text { Job Rotation } \\
\text { Job rotation program for career } \\
\text { development; informal job rotation. }\end{array}$ & $\begin{array}{l}\text { Cohen and Levinthal (1990); Daugfous, } \\
\text { 2004; Jansen et. al., (2005) }\end{array}$ \\
\hline
\end{tabular}

Revista Eletrônica de Estratégia \& Negócios, Florianópolis, v.14, n. 2, mai./ago. 2021. 


\begin{tabular}{|c|c|c|}
\hline $\begin{array}{c}\text { Absorptive Capacity } \\
\text { Dimensions }\end{array}$ & Antecedents of Absorptive Capacity & Theoretical Basis \\
\hline & $\begin{array}{l}\text { Socialization } \\
\text { Shared spaces dedicates to team } \\
\text { socialization; common areas for } \\
\text { socialization with companies; special } \\
\text { moments for socialization activities. }\end{array}$ & $\begin{array}{l}\text { Daugfous, 2004; Jansen et. al., (2005); } \\
\text { Flatten et. al. (2011) }\end{array}$ \\
\hline & $\begin{array}{l}\text { new knowledge application, idea } \\
\text { generation } \\
\text { Mechanisms to encourage the } \\
\text { generation of ideas (awards); favorable } \\
\text { culture for the implementation of ideas } \\
\text { (freedom and trust). }\end{array}$ & $\begin{array}{l}\text { Daugfous, 2004; Jansen et. al., (2005); } \\
\text { Flatten et. al. (2011). }\end{array}$ \\
\hline \multirow[b]{2}{*}{$\begin{array}{l}\text { Realized Absorptive Capacity } \\
\text { (Exploitation) }\end{array}$} & $\begin{array}{l}\text { Formalization Tools } \\
\text { Reports; information system networks; } \\
\text { personalized information systems; } \\
\text { document sharing on cloud. }\end{array}$ & $\begin{array}{l}\text { Tu et. Al. (2006); Jansen et. al., (2005); } \\
\text { Jiménez-Barrionuevo et. al., (2011). }\end{array}$ \\
\hline & $\begin{array}{l}\text { Generation of new products and } \\
\text { services } \\
\text { Evidence of the generation of products, } \\
\text { projects and services resulting from } \\
\text { environmental scanning activities such as } \\
\text { benchmarking and networking with } \\
\text { stakeholders (L.O.U.Co -; Pitching for } \\
\text { Funding; Embraer certification). }\end{array}$ & $\begin{array}{l}\text { Camisón and Forés (2009); Flatten et. al. } \\
\text { (2011) }\end{array}$ \\
\hline
\end{tabular}

Source: Elaborated by the authors, 2021.

\section{FINAL CONSIDERATIONS}

The objective of this study was to analyze how the dimensions of the absorptive capacity are evidenced in the technological parks, from the processes of environmental monitoring.

In order to do so, this work has sought together with the literature and studies on the construct absorptive capacity, since its original proposition and its improvement in the last decades. This research identified the main contributions of the studies especially with regard to the antecedents that positively influence the absorptive capacity in organizations.

As a result of the interview analysis, evidence of the development of the absorptive capacity was found in all the studied parks. Analyzes show that parks, regardless of location or size, maintain a dynamic of environmental monitoring with similarities as sources of information, benchmarking, partnerships with other organizations, participation in forums, 
and association with networks. However, when it comes to monitoring trends and new technologies, only one of the parks mentioned the university as a source of information.

This found was in according to the Schweisfurth and Raasch (2018, p. 694) study', in which they increase their "understanding of absorptive capacity in knowledge domains other than technological solutions, specifically in the need knowledge domain, and to analyze its principal antecedents and consequences for innovation."

In relation to the assimilation of acquired new knowledge, the parks focus on face-toface interaction, with team meetings being the main communication instrument identified. What attracted attention was the fragility of some parks regarding structured programs for the training of their employees, mainly because they are organizations closely related to academic institutions.

The transformation of externally acquired knowledge is facilitated by support for the generation and implementation of ideas, and the provision of spaces and activities for social interaction in all the studied environments. Job rotation, though instituted in some settings, is not a consolidated practice in most parks. This observation presents itself as an opportunity to be worked by the parks, as a way of instigating the interaction between areas, increasing the capacity to transform the new knowledge from the association with the existing knowledge.

Concerning exploration of acquired new knowledge, the parks have shown, with some peculiarities, the existence of processes or tools to formalize and store the acquired information. In addition, all parks have demonstrated the ability to create new products and services, from information acquired in environmental monitoring, and for the purpose of renewing and evolving their innovation environments.

\section{REFERENCES}

ALBRIGHT, K. S. Environmental scanning: radar for success. Information Management, v. 38, n. 3, p. 38-45, May/Jun. 2004.

ANNERSTEDT, J. Science parks and high-tech clustering. In: BIANCHI, P.; SANDRINE, L. (ed.). International Handbook on Industrial Policy. Cheltenham: Edward Elgar Publishing., 2006. Cap. 14.

Revista Eletrônica de Estratégia \& Negócios, Florianópolis, v.14, n. 2, mai./ago. 2021. 
BARDIN, L. Análise de conteúdo. Lisboa: Edições 70, 1995.

CAMISÓN, C.; FORÉS, B. Knowledge absorptive capacity: new insights for its conceptualization and measurement. Journal of Business Research, v. 63, n. 7, p. 707-715, Jul. 2010.

CASTELLS, M.; HALL, P. Technopolis of the World: the making of twenty-first century industrial complexes. London; New York: Routledge, 1994. E-Book.

CHOO, C. W.; AUSTER, E. Environmental scanning: acquisition and use of information by managers. Annual Review of Information Science and Technology (Arist), v. 28, p. 279-314, 1993.

$\mathrm{CHOO}, \mathrm{C} . \mathrm{W}$. Environmental scanning as information seeking and organizational learning. Information Research, v. 7, n. 1, p. 1-25, Oct. 2001.

COHEN, W. M.; LEVINTHAL, D. A. Innovation and Learning: the two faces of R \& D. The economic journal, v. 99, n. 397, p. 569-596, Sep. 1989.

COHEN, W. M.; LEVINTHAL, D. A. Absorptive capacity: a new perspective on learning and innovation. Administrative Science Quarterly, v. 35, n. 1, p. 128-152, Mar. 1990.

DAFT, R. L.; SORMUNEN, J.; PARKS, D. Chief executive scanning, environmental characteristics, and company performance: an empirical study. Strategic management journal, v. 9, n. 2, p. 123-139, Apr. 1988.

DAGHFOUS, A. Absorptive capacity and the implementation of knowledge-intensive best practices. SAM Advanced Management Journal, v. 69, n. 2, p. 21, 2004.

FERREIRA, G. C.; FERREIRA, J. J. M. Absorptive capacity: an analysis in the context of Brazilian family firms. Revista de Administração Mackenzie, São Paulo, v. 18, n. 1, p. 174-204, Jan./Feb. 2017. Available in:

https://www.scielo.br/j/ram/a/hRdpLXWK8f4cp6cvhTRrZXL/?lang=en. Access in: 25 Aug. 2021.

FLATTEN, T. C. et al. A measure of absorptive capacity: Scale development and validation. European Management Journal, v. 29, n. 2, p. 98-116, Apr. 2011.

GYURKOVICS, János; LUKOVICS, Miklós. Generations of Science Parks in the Light of Responsible Innovation. In: Buzás N; Lukovics M Szerk.: Responsible Innovation. Szeged: University of Szeged, 2014. pp. 193-208.

HASSINK, R.; HU, X. From specialization to diversification in science and technology parks. World Technopolis Review, v. 1, n. 1, p. 6-15, 2012.

IASP. Málaga, 2017. Available in: https://www.iasp.ws/About-us/IASP-in-a-few-words. Access in: 16 Mar. 2017. 
JANSEN, J. J. P.; VAN DEN BOSCH, F. A. J.; VOLBERDA, H. W. Managing potential and realized absorptive capacity: how do organizational antecedents matter? Academy of management journal, v. 48, n. 6, p. 999-1015, 2005.

JIMÉNEZ-BARRIONUEVO, M. M.; GARCÍA-MORALES, V. J.; MOLINA, L. M. Validation of an instrument to measure absorptive capacity. Technovation, v. 31, n. 5-6, p. 190-202, May/Jun. 2011.

LEWIN, A. Y.; MASSINI, S.; PEETERS, C. Microfoundations of internal and external absorptive capacity routines. Organization Science, v. 22, n. 1, p. 81-98, Jan./Feb. 2011.

LUNARDI, M. E. Parques tecnológicos: estratégias de localização em Porto Alegre, Florianópolis e Curitiba. [S. I.]: Ed. do Autor, 1997.

MINBAEVA, D. B. et al. MNC knowledge transfer, subsidiary absorptive capacity and HRM. Journal of International Business Studies, v. 34, n. 5, p. 586-599, 2003.

MORAES, Roque. Análise de conteúdo. Revista Educação, Porto Alegre, v. 22, n. 37, p. 7-32, 1999.

MORENO, V., A. S.; COELHO, M.; PITASSI, C. Outsourcing of IT and Absorptive Capacity: a multiple case study in the Brazilian insurance sector. Brazilian Business Review, Rio de Janeiro, v. 17, n. 1, p. 97-113, Jan./Feb. 2020 Available in:

http://bbronline.com.br/index.php/bbr/article/view/561. Access in: 25 Aug. 2021.

MUROVEC, N.; PRODAN, I. Absorptive capacity, its determinants, and influence on innovation output: Cross-cultural validation of the structural model. Technovation, v. 29, n. 12, p. 859-872, Dec. 2009.

NIKINA, A.; PIQUÉ, J. Areas of innovation in a global world: concept and practice. Malaga: International Association of Science Parks and Areas of Innovation, 2016. E-Book.

PHAN, P. H.; SIEGEL, D. S.; WRIGHT, M. Science parks and incubators: observations, synthesis and future research. Journal of business venturing, v. 20, n. 2, p. 165-182, 2005.

SANZ, L. From Technology Parks to Learning Villages: A Technology Park Model for the Global Society. In: WORLD CONFERENCE ON SCIENCE \& TECHNOLOGY PARKS, 18., Bilbao Proceedings [...] Espanha, 2001. Available in: https://www.iasp.ws/ourindustry/knowledge-room. Access in: 12 Fev. 2018.

SCHWEISFURTH, T. G.; RAASCHB, C. Absorptive capacity for need knowledge: Antecedents and effects for employee innovativeness. Research Policy, v. 47, n. 4, p. 687-699, May. 2018.

TODOROVA, G.; DURISIN, B. Absorptive capacity: Valuing a reconceptualization. Academy of management review, v. 32, n. 3, p. 774-786, Jul. 2007.

TU, Q. et al. Absorptive capacity: enhancing the assimilation of time-based manufacturing practices. Journal of operations management, v. 24, n. 5, p. 692-710, Sep. 2006. 
VAN DEN BOSCH, F.; VAN WIJK, R.; VOLBERDA, H. W. Absorptive capacity: Antecedents, models and outcomes. In: ERIM report series research in management. Rotterdam: Rotterdam School of Economic, 2003.

VEGA-JURADO, J.; GUTIÉRREZ-GRACIA, A.; FERNÁNDEZ-DE-LUCIO, I. Analyzing the determinants of firm's absorptive capacity: beyond R\&D. R\&D Management, v. 38, n. 4, p. 392-405, Sep. 2008.

YIN, Robert K. Estudo de caso: uma estratégia de pesquisa. São Paulo: Saraiva, 2009.

ZAHRA, S. A.; GEORGE, G. Absorptive capacity: A review, reconceptualization, and extension. Academy of management review, v. 27, n. 2, p. 185-203, 2002. 